\title{
Pengaruh Likuiditas dan Solvabilitas Terhadap Rentabilitas Ekonomis pada Koperasi Sawit Usaha Manunggal Desa Seresam Kecamatan Seberida Kabupaten Indragiri Hulu
}

\author{
Irawati $^{1}$, Fitria Ningsih ${ }^{2}$ \\ 1.2. Program Studi Manajemen, Sekolah Tinggi Ilmu Ekonomi Indragiri (STIE-I) Rengat \\ Correspondence email: irawati@stieindragiri.ac.id, ${ }^{2}$ fitrianingsih@ stieindragiri.ac.id
}

\begin{abstract}
This research was conducted at Manunggal Palm Oil Cooperative in Seresam Village, Seberida District, Indragiri Hulu Regency. Researchers. The research was started from 2013 to 2018. The analysis applied the quantitative method with Multiple Linear Regression, Correlation Coefficient and determination and then testing the hypothesis using SPSS Version 21. The result of this research is that liquidity has no effect on economic profitability. While solvency affects economic rentability. While simultaneous liquidity and solvency affect economic profitability.
\end{abstract}

Keywords: Liquidity; Solvency; Economic Rentability

\section{Pendahuluan}

Koperasi sebagai salah satu sektor kekuatan ekonomi diharapkan dapat dijadikan sebagai soko guru perekonomian Indonesia, karena koperasi merupakan suatu badan usaha yang sesuai dengan demokrasi ekonomi bangsa Indonesia yaitu dari rakyat, oleh rakyat dan untk kesejahteraan rakyat. Koperasi sebagai badan usaha, selain bertujuan untuk memenuhi kebutuhan anggota, koperasi juga mempunyai tujuan yaitu mencapai keuntungan (Sisa Hasil Usaha). Koperasi Sawit Usaha Manunggal Desa Seresam Kecamatan Seberida mempunyai tugas pokok yang sama dengan koperasi-koperasi yang ada di Indonesia yaitu memajukan kesejahteraan anggota pada khususnya dan masyarakat Indonesia pada umumnya serta ikut membangun tatanan perekonimian nasional dalam rangka mewujudkan masyarakat yang maju, adil dan makmur yang berlandaskan Pancasila dan Undang Undang Dasar 1945. Hal ini dilakukan dengan cara menjalankan kegiatannya dengan sebaik-baiknya dalam wilayah tertentu.

Suatu usaha koperasi agar dapat terus berjalan maka koperasi tersebut haruslah menghasilkan laba. Akan tetapi karena koperasi berwatak social maka mencari laba bukan untuk perorangan tetapi untuk kemakmuran seluruh anggotanya.Oleh karena itu koperasi perlu memperhatikan kinerja keuangannya agar koperasi dapat terus menjalankan aktivitas operasionalnya supaya kelangsungan usaha koperasi tetap terus terjaga.Salah satu aspek pengelolaan keuangan koperasi yaitu dengan melakukan pencatatan dalam bentuk laporan keuangan.Alat-alat yang digunakan untuk menganalisis laporan keuangan adalah dengan menggunakan analisis rasio keuangan yang meliputi likuiditas, solvabilitas dan rentabilitas.

Rentabilitas adalah kemampuan perusahaan untuk menghasilkan laba selama periode tertentu. (Munawir, 2014). Rentabilitas merupakan rasio untuk menilai kemampuan perusahaan dalam mencari keuntungan.Rasio ini juga memberikan ukuran tingkat efektifitas manajemen suatu perusahaan.Hal ini ditunjukkan oleh laba yang dihasilkan dari penjualan dan pendapatan investasi. (Kasmir, 2014)

Tabel 1

Perkembangan Sisa Hasil Usaha Koperasi Sawit Usaha Manunggal Desa Seresam Kecamatan Seberida tahun 2013 - 2018

\begin{tabular}{ccrr}
\hline No. & Tahun & Sisa Hasil Usaha (Rp.) & Persentase (\%) \\
\hline 1. & 2013 & $1.238 .393 .592,-$ & 0 \\
2. & 2014 & $657.242 .251,-$ & $(53,07)$ \\
3. & 2015 & $429.457 .620,-$ & $(65,34)$ \\
4. & 2016 & $232.956 .259,-$ & $(54,24)$ \\
5. & 2017 & $392.184 .433,-$ & $168,35 \%$ \\
6. & 2018 & $540.748 .425,-$ & $137,88 \%$ \\
\hline
\end{tabular}

Sumber : Koperasi Sawit Usaha Manunggal, Tahun 2019.

Berdasarkan Tabel 1 di atas dapat dilihat bahwa dari Sisa Hasil Usaha dari tahun 2013 sampai 2016 setiap tahunnya mengalami penurunan, kemudian baru tahun 2017 sampai 2018 mengalami kenaikan, secara persentasenya terlalu berfluktuasi. Penelitian ini bertujuan untuk mengetahui pengaruh likuiditas dan solvabilitas terhadap rentabilitas ekonomis pada koperasi sawit usaha manunggal desa Seresam Kecamatan Seberida Kabupaten Indragiri Hulu. 
Irawati dan Fitria Ningsih, Pengaruh Likuiditas dan Solvabilitas Terhadap Rentabilitas Ekonomis pada Koperasi Sawit Usaha Manunggal Desa Seresam Kecamatan Seberida Kabupaten Indragiri Hulu

Tinjauan Teori

Rentabilitas

Rentabilitas atau Profitability adalah menunjukkan kemampuan perusahaan untuk menghasilkan laba selama periode tertentu.Rentabilitas suatu perusahaan diukur dengan kesuksessan perusahaan dan kemampuan menggunakan aktivanya secara produktif, dengan demikian rentabilitas suatu perusahaan dapat diketahui dengan memperbandingkan antara laba yang diperoleh dalam suatu periode dengan jumlah aktiva atau jumlah modal perusahaan tersebut. (Munawir, 2014). Rentabilitas modal sendiri merupakan suatu pengukuran dari penghasilan (income) yang tersedia bagi pemilik modal perusahaan atas modal yang mereka investasikan di dalam perusahaan. (Syamsudin, 2011; 64)

\section{Likuiditas}

Rasio Likuiditas merupakan rasio yang mengukur kemampuan perusahaan memenuhi kewajiban jangka pendeknya. (Harahap dkk, 2009). Likuiditas adalah menunjukkan kemampuan suatu perusahaan untuk memenuhi kewajiban keuangannya yang harus segera dipenuhi, atau kemampuan perusahaan untuk memenuhi kewajiban keuangan pada saat ditagih. (Munawir, 2014). Rasio likuiditas berfungsi untuk menunjukkan atau mengukur kemampuan perusahaan dalam memenuhi kewajiban yang sudah jatuh tempo, baik kewajiban pada pihak luar perusahaan (likuiditas badan usaha) maupun di dalam perusahaan (likuiditas perusahaan). (Kasmir, 2015)

\section{Solvabilitas}

Solvabilitas merupakan kemampuan perusahaan memenuhi seluruh kewajibannya bila perusahaan dinyatakan bangkrut atau dilikuidasi dengan seluruh asset yang dimilikinya. (Supriasi dan Sofyana, 2012). Solvabilitas adalah kemampuan perusahaan untuk membayar semua utang-utangnya, baik utang jangka pendek maupun utang jangka panjang. Solvabilitas diukur dengan perbandingan antara total aktiva dengan total utang. Ukuran ini mensyaratkan agar perusahaan mampu memenuhi semua kewajibannya, baik jangka pendek maupun jangka panjang. (Sugiyarso, 2011)

\section{Metode}

Penelitian ini langsung pada Koperasi Sawit Usaha Manunggal Desa Seresam Kecamatan Seberida Kabupaten Indragiri Hulu. Penelitian berlangsung lebih kurang 3 bulan. Terhitung Oktober 2019 sampai dengan Desember 2019. Alat analisis yang digunakan dalam penelitian ini adalah metode kuantitatif, yaitu penelitian yang menggambarkan tentang Likuiditas dan Solvabilitas terhadap Rentabilitas, dengan menggunakan Regresi Linear Berganda.

\section{Hasil}

Tabel 2

Rekapitulasi Hasil Uji Regresi Berganda

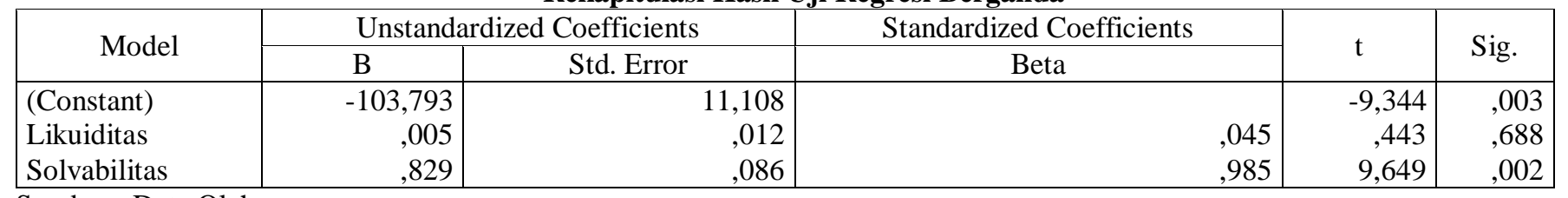

Sumber : Data Olahan

Persamaan regresi linear berganda sebagai berikut:

$\mathrm{Y}=-103,793+0,005 \mathrm{X} 1+0,829 \mathrm{X} 2$

$\mathrm{a}=-103,793$; jika likuiditas dan solvabilitas sama dengan 0 (nol), maka rentabilitas ekonomis adalah sebesar -103,793.

$\mathrm{b}_{1}=0,005$; jika likuiditas naik sebesar satu satuan sementara solvabilitas adalah nol atau tetap, maka rentabilitas ekonomis akan naik sebesar 0,005 poin.

$\mathrm{b}_{2}=0,829$; jika solvabilitas naik sebesar satu satuan sementara likuiditas adalah nol atau tetap, maka rentabilitas ekonomis akan naik sebesar 0,829 poin.

Tabel 3

Koefisien Determinasi

\begin{tabular}{|c|r|r|r|r|}
\hline Model & R & R Square & Adjusted R Square & Std. Error of the Estimate \\
\hline 1 &, $984^{\mathrm{a}}$ &, 969 & &, 948 \\
\hline
\end{tabular}

Sumber : Data Olahan 
Irawati dan Fitria Ningsih, Pengaruh Likuiditas dan Solvabilitas Terhadap Rentabilitas Ekonomis pada Koperasi Sawit Usaha Manunggal Desa Seresam Kecamatan Seberida Kabupaten Indragiri Hulu

Koefisien determinasinya adalah sebesar 0,969 yang berarti bahwa variabel rentabilitas ekonomis dijelaskan oleh variabel likuiditas dan solvabilitas sebesar 96,9\% sedangkan sisanya sebesar 3,1\% disumbangkan oleh variabel bebas lainnya yang tidak diteliti dalam penelitian ini

\section{Uji Simultan}

Tabel 4

Uji Simultan

\begin{tabular}{|c|c|c|c|c|c|}
\hline Model & Sum of Squares & Df & Mean Square & $\mathrm{F}$ & Sig. \\
\hline Regression & 31,582 & 2 & 15,791 & 46,569 &, $006^{\mathrm{b}}$ \\
\hline Residual & 1,107 & 3 & 0,339 & & \\
\hline Total & 32,600 & 5 & & & \\
\hline
\end{tabular}

Sumber : Data Olahan

Diperoleh nilai $\mathrm{F}_{\text {hitung }} 46,569>9,55 \mathrm{~F}_{\text {tabel }}$ maka berdasarkan kriteria pengujian data dapat diketahui $\mathrm{H}_{0}$ ditolak dan $\mathrm{H}_{\mathrm{a}}$ diterima, artinya secara bersama-sama antara likuiditas dan solvabilitas berpengaruh signifikan terhadap rentabilitas ekonomis.

\section{Uji Parsial}

Berdasarkan Tabel 2 sebelumnya dijelaskan bahwa untuk variable likuiditas, t-hitung $0,443<2,77645$, berdasarkan kriteria pengujian diketahui bahwa $\mathrm{H}_{0}$ diterima dan $\mathrm{H}_{\mathrm{a}}$ ditolak, artinya likuiditas secara parsial berpengaruh tetapi tidak signifikan terhadap Rentabilitas Ekonomis. Variable Solvabilitas, t hitung 9,649>2,77645, berdasarkan kriteria pengujian diketahui bahwa $\mathrm{H}_{0}$ ditolak dan $\mathrm{H}_{\mathrm{a}}$ diterima, artinya Solvabilitas secara parsial berpengaruh dan signifikan terhadap Rentabilitas Ekonomis.

Hasil penelitian ini menunjukkan bahwa likuiditas terhadap rentabilitas ekonomis disini tidak signifikan. Hal ini tidak sama dengan penelitian terdahulu menurut Supriadi dan Sofyana (2012) diketahui bahwa likuiditas berpengaruh terhadap Rentabilitas. Hal ini dikarenakan total kas dan bank nya terlalu kecil dibandingkan dengan hutang lancar, sehingga tingkat likuiditas dari Koperasi Sawit usaha manunggal desa Seresam ini terlalu rendah. Dimana hasilnya ratarata di bawah seratus persen.Dengan asumsi untuk hal yang demikian ini perusahaan tidak mampu melunasi hutang jangka pendeknya.Hal ini disebabkan karena likuiditas dari Koperasi Sawit Usaha Manungal Desa Seresam Kecamatan Seberida Kabupaten Indragiri Hulu ini sangat rendah sekali.Dimana Likuiditasnya masih dibawah seratus persen.Menurut teori jika kondisi seperti ini dimana koperasi ini tidak mampu melunasi hutang jangka pendeknya. Penelitian mengenai pengaruh solvabilitas terhadap rentabilitas ekonomis dalam hal ini berpengaruh signifikan. Sesuai dengan penelitian Hariwangsa dan Wirawati (2017) yang hasilnya solvabilitas berpengaruh terhadap Rentabiltas.Dari hasil perhitungan tingkat solvabilitas dari Koperasi ini sudah cukup tinggi karena sudah diatas seratus persen.Dalam arti jika koperasi ini dilikuidasi dia sudah mampu untuk melunasi hutang jangka pendek dan jangka panjangnya. Penelitian mengenai pengaruh dari likuiditas dan solvabilitas terhadap rentabilitas ekonomis dalam hal ini ada pengaruhnya.Kemudian dari segi hubungannya juga mempunyai hubungan yang sangat kuat.

\section{Simpulan}

Hasil penelitian menyimpulkan bahwa secara simultan likuiditas dan solvabilitas berpengaruh terhadap rentabilitas ekonomis dan secara parsial likuiditas tidak berpengaruh terhadap rentabilitas ekonomis .pada Koperasi Sawit Usaha Manunggal Desa Seresam Kecamatan Seberida Kabupaten Indragiri Hulu

\section{Daftar Pustaka}

Any, Ulfah dan Nadir, 2011, Analisis Rasio Likuiditas, Solvabilitas dan Rentabilitas dalam menilai kinerja Keuangan pada Perum Damri Setasiun Samarinda.

Aprianti, 2014, Analisis Kinerja Keuangan Ditinjau dari Aspek Likuiditas, Solvabilitas dan Rentabilitas pada PT. Surya Teguh Perkasa Samarinda.

Fahmi, Irham, 2014, Pengantar Manajemen Keuangan, Alfabeta, Bandung.

Hanafi, Mamduh M, 2008, Manajemen Keuangan, Edisi I, BPFE, Yogyakarta.

Harahap, Sofyan, Safri, 2009, Teori Akuntansi, Raja Grafindo, Jakarta.

Hariwangsa dan Wirawati, 2017, Efektifitas modal Sendiri, Likuiditas dan Solvabilitas terhadap tingkat Rentabilitas pada Koperasi Karyawan Cipta Usaha.

Kasmir, 2015, Analisis Laporan Keuangan, Raja Grafindo Persada, Jakarta.

Munawir, 2014, Analisis Laporan Keuangan, Liberty, Yogyakarta. 
Irawati dan Fitria Ningsih, Pengaruh Likuiditas dan Solvabilitas Terhadap Rentabilitas Ekonomis pada Koperasi Sawit Usaha Manunggal Desa Seresam Kecamatan Seberida Kabupaten Indragiri Hulu

Nurfauji, 2012, Pengaruh Kualitas Aktiva Produktif, Kecukupan modal dan Likuiditas terhadap Rentabilitas pada PT. BPR Artha.

Riyanto, Bambang, 2010, Dasar-dasar Pembelanjaan Perusahaan, BPFE, Yogyakarta.

Sigiyarso, Gervasius, 2011, Akuntansi Koperasi Sistem, Metode dan Analisis Laporan Keuangan, Caps, Yogyakarta.

Subramanyam, KR dan John, J. Wild, 2011, Analisis Laporan Keuangan, Buku Satu, Edisi Sepuluh, Salemba Empat, Jakarta.

Supriadi dan Sofyana, 2012, Analisa Pengaruh Likuiditas dan Solvabilitas Terhadap Rentabilitas Pada Koperasi Karyawan PLN Cipta Usaha, Jurnal Ilmiah Ranggading, Vol. 12 No. 2 Oktober 2012; 186-192

Sutrisno, 2009, Manajemen Keuangan Teori, Konsep dan Aplikasi, Edisi Pertama, Ketakan Ketujuh, Penerbit Ekonisia, Yogyakarta.

Syamsudin, Lukman, 2011, Manajemen Keuangan Perusahaan, PT. Raja Grafindo, Jakarta. 